\title{
PRACTICAL EXPERIENCE
}

GPOULTRY $\cong$

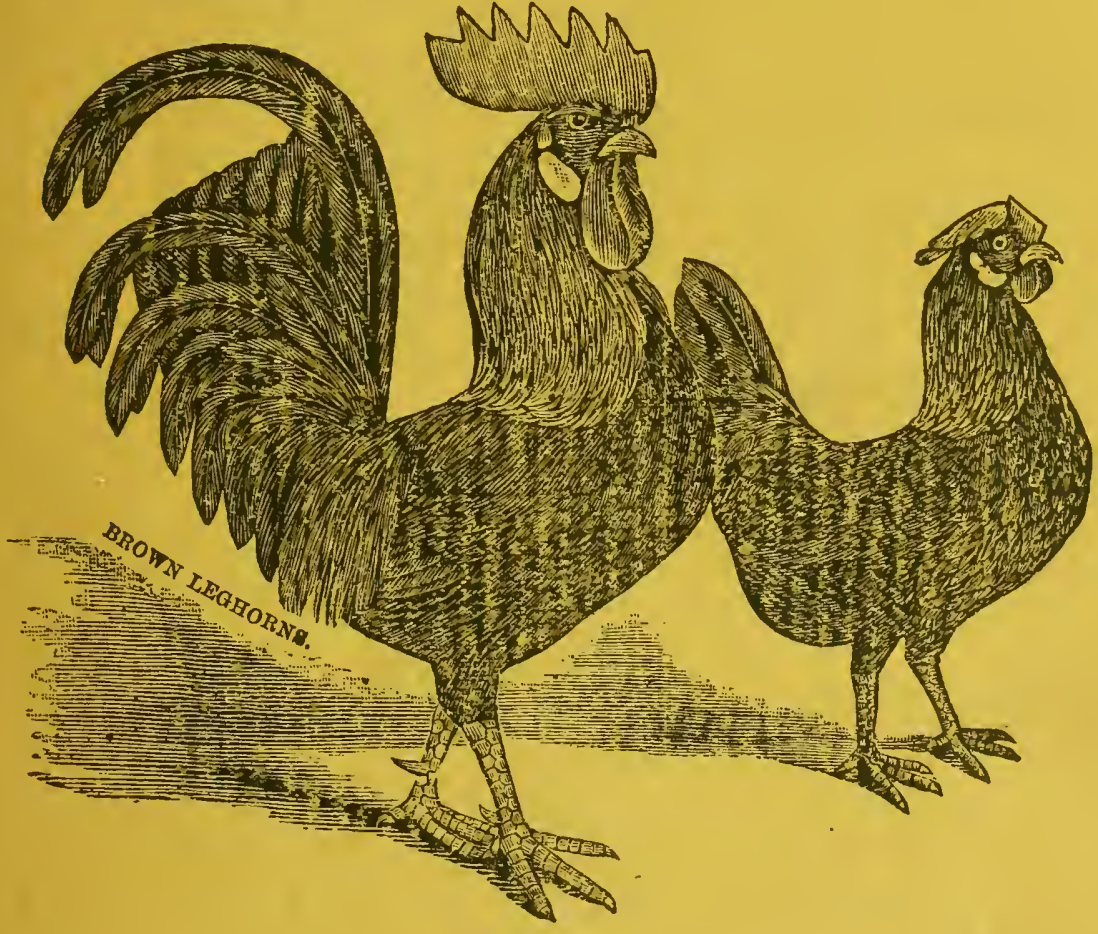

GEO. M. DAVENPORT.

Price, 25 Cents. 



\section{PRACTICAL EXPERIENCE}

- YXITH-
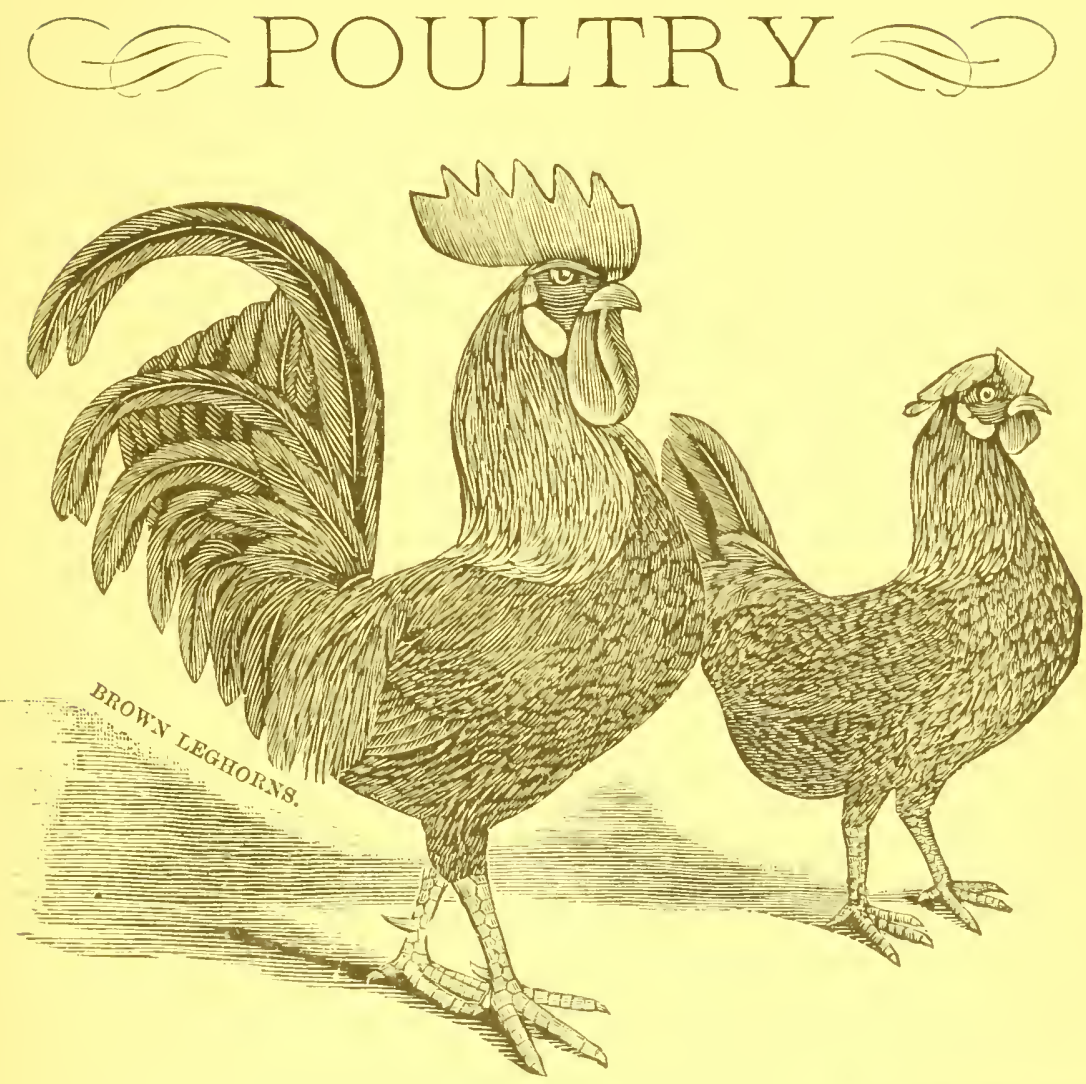

- - BY-

ᄂ

GEO. M. DAVENPORT.

Price, - $\quad 25$ Cents. 
ENTERED ACCORDING TO ACT OF CONGRESS,

AT THE LIERARIAN'S OFFICE

WASHINGTON, D. C.

BY

GED. I.. IAYEITPORT.

GEO, H. BURNHAM \& CO., PRINTERS,

18. WEST HOUSTON STREET,

NEW YORK. 


\section{PREFACE.}

This Book is intended to fill a void long felt, among practical poultry growers. We mean a treatise that shall combine all the information contained in larger works, without their verbosity and come within the means of every child who can procure a dozen of eggs. 


\section{DEDICATION.}

To the women and children of New England:-I dedicate my little work on Poultry, with the sincere wish that they may derive that benefit from it the Author intended and which they so richly deserve. The Author. 


\section{Practical Experience with Poultry.}

In placing before the public my practical experience with poultry, I am actuated with a desire to benefit the working farmer. Yet it can be of service to others than the practical agriculturalist. The centralization of population to villages and cities the past few years, and the importation from the West of the great staples of productions such as corn, wheat, beef, pork, and many other products formerly produced in the past has worked very disastronsly for the farmer in the East and Middle States. Under the present condition of things he must seek some other branch of industry to procmre his snbsistence from the soil. Poultry, which has heretofore been looked upon as one of the extras of the farm, can be made a specialty, and with a due exercise of brain and intelligence made profitable, and not as laborious as many former branches of work. It is not my purpose in this preface to write a homily upon labor, or what has produced the present condition of the farmer. It is sufficient to know it is so, and some method should be songht to change it : that we fit ourselves to existing circumstances, if the old methods no longer pay, ascertain what can be made profitable on. the farm, but do not forsake the old home, and the only employment you understand, for new homes and some employment you do not understand. Tou hare learned not to coret all the land that joins you, you must also learn not to attempt to cultivate more land than you can cultivate to advantage. You cannot exercise the mind mentally in thought and study, if you are physically exhausted, We have known people to live years in one locality, hardly making a living, while some new comer would see a way to better his condition. I look upon the present degenerate condition of the farmer as being produced by circunstances he might have controlled, but for lack of foresight in the past. Now let us take soundings, see where we are, and if we are in a bad condition, study some way to extricate ourselves. The United States the past year, 1855, imported sixteen millions four hundred and eightyseven thousand two hundred and fom dozen of eggs, at the cost of two million six humdred and seventy-seven thousands three hundred and sixty dollars. This is appalling. This is an agricultural country, who boast they feed the world, and yet camnot supply themselves with egrs-whose reasons for not raising farm produce has been, in the past, that they cannot sell it; that the home market is glutted. This does not apply to egros alone as regards importation of farm products easily produced hy the working farmer. We sinsply state it in its application to our subject. Every farmer can, and should, give esch son and daughter who has arrive at ten years of age land and suitable fixings for one humcled hens, giving them an early insight of the duties of life. bringing with it an independence of thought a glinpse of 
their responsibilities as a higher order of beings. Teaching them work is recreation, not a task; that resonable labor is elevating; that idleness is debasing. You may think ten years is too early to learn; yet you would not think four years too early to learn the complications of the alphabet. The farm can be made the children's school, illustratively, if you will do your part. We all linow that children in cotton mills unclerstand the workings of machinery at ten years, learned muder discipline as wage-workers. We also know they will learn much quicker when appeal is made to their reason muder the loving guidence of a father or mother. Never be harsh with them, and they will always come to you for counsel, nerer resorting to duplicity. When passed the meridian of life, a complete change in our circumstances compelled us to resor't to some occupation, not only for a subsistance, but to divert our mind from the debris of the past. A friend suggested poultry, which advice we acted upon.

I intend to give the reader in detail what I learned in two year's' experience in the management of poultry, making a specialty of eggs and breeding chickens for practical purposes, giving the subject careful attention and sparing nothing that would enable me to obtain a lnowledge which shonld be satisfactory to me, a net profit could be derived from lieeping poultry as a legitimate business. My experiments the first year lessened the net results from what they would have been had I possessed the knowledge I now undertake to impart to the reader; yet there was no time during these two years that I did not receire from my labor a fair remmeration : and from my practical expcrience I claim there is nothing in the present conditions of the practical farmer that pays as well in New England, for however low other products may be or forestalled by capitalists, the successful management of poultry depends on slitl and intelligence, placing it beyond the reach of the ignorant and imcompetent. Neither can the market be forestalled for high prices on the consumer by moneyed power. No corner can be made on eggs.

If the farmer of New England (and this will apply to the Middle States sit the prescnt timc) must depend on his daily sales of milk, butter, vegetrbles, fuit, poulty and eggs, and all these products excepts cgos are more or liss affected by foreign producers who in the season will flood the East with regetables and fruit from the Pacific coast, the Sonthern States and Bermuda, the Test packing her butter and condensing her milk, the Northem egg will still maintain its price. Again I reiterate, the poultry product in the East is prramount to all others.

The business can be enlarged to any limit that those engaged are endowed with capacity. Capital may be desired at the start-industry, ability and perseverance will make the capital only a question of tme.

I do not intend to state anything in this short treatise that would cause the new beginner to lose money, or time, which is of more value than money, and if he does, I assert it will be from neglect of the rules I here advance. 
And at this point I must say 75 per cent. of those engaging in the rocation will fail from neglect of details, hence the monopoly for the competent and persevering engaged in the occupation.

I commenced in the month of October with 50 hens, continuing twenty-sixmonths, the first year breeding all the chickens I eould, experimenting with every feed. In fact, my first year was a tissue of experiments, both book and brain, and I never realized the magnitude of my employment at the outset.

The second year fomd me with one hundred and forty hens including two pture light Brahma roosters and two Brown Leghorns, with twelve pure Light Brahma pullets and the same number of pure Brown Leghorns; the remainder were grades of every description. My product the second year was 1,353 dozen of eggrs sold to consumers, excepting those consumed in the family and. set for chicks, which were rated at tho samo price as those sold when thus used. The extreme of prices was 16 and 36 cents per dozen, averaging twenty-six cents per dozen. My eggs were sold in the city of Worcester, Mass., during the months of March and April, when there was a surplus of eggs in the market I set thirty-four dozen, never setting over nine eggs under one hen, and in most instances seven-raising one hundred and sixtyfour ehickens, about equally divided in sex; I lost about fifty per cent. of my ehicks by a cold storm.

The net profit from all sold and consumed, viz, dressed poultry, eggs, manure and feather's, was one dollar and thirty-six cents per hen, amounting to $\$ 184.96$. I believe, had I continued the following year, I conld have carried the net gain to a much higher figure, for I learned my success was proportionate to my experience. The question is simply this, can you ascertain what is required for one hen? and if you can supply one hen all that is wanting for success, can you extend it to unlimited numbers?

There should be at all times in the hennery or yard raw regetables, but they should never be cooked. I prefer potatoes or turnips, the turnips to be cut throngh the eentre, but beets, carrots, parsnips, pumpkin, squash or sweet apple will answer. Vegetables of some kind are necessary. If boiled they elog the crop. Have a box of cracked bone, oyster shells and pounded flint stone eonvenient for them. The stone you can pulverize with a heavy hammer on another stone. Tieep each article separate, and remove them at night from the house. They ean stand out permanently when the hens are rumning at large. Occasionally cut the vegetables fine as corn. In the winter they must have fresh meat. Take a beef's head, hang it in such a position that they will have to jump about a foot for it, then they will not eat enough to injure them and the exercise is necessary. Remove the head at night from the house. In summer feed scraps twice each week. Fresh meat taints too quick in hot weather, and it is important that no tainted food be fed. Again we affirm, the hen properly eared for will eat no impurity. If one lives in the vicinity of a pop-corn factory, he can procure the siftings from the 
imperfect popcorn. It can be purchased much less then its real value, and it is tho most valuable of all feeds for either hens in the laying, or growing chickens. One factory in the city of New York makes six hundred bushels annually of this feed.

The hen must be kept quiet. Allow no officious visitors to ramble about the yard; it annoys them. They love and know their attendant, desiring no other company. Keep the hen free from all excitement. Never was the phrase, "Business begets business," better exemplified than in one hen exciting" another to lay eggs by her demonstrations. Hens must not be permitted to eat snow or drink snow-water, and the same applies to rain-water or water in sink-drains; all soft waters are physicking to poultry. Hard or lime water is best-we do not mean water from steeped lime which should be avoided.

The constant attendant can gather the eggs when he pleases, and he need never act slyly or go skulking about this work; nothing more disgusts the hen, unless boisteronsness. The hen will be pleased to witness the interest he takes in the business. Remember, this only applies to the constant attendant. The gathering of the eggs is the only part of the work you need have no rule for. Remove the windows in extreme hot days, or shade them so as not to reflect the sum. Endeavor as nearly as possible to keep the house at a temperature of 65 to 70 degrees. They do not iay as well in extremes or either heat or cold as in an even temperature.

Localitr. - In starting a poultry yard a southern exposure is to be preferved. It is also desirable to be sheltered from winds and dranghts as much as possible. One acre of land is sufficient for one lundred fowls. This gives an area of 272 superficial feet per hen. One-eighth of this should be free from grass or vegetation, and once in two weeks should be spaded or ploughed, sowing one-half bushel of oats oxer the surface before spading: The hens will soon find there are oats in the soil and never cease working it for more. This employment is an important item in the business. Many of the oats will not be found until sprouted. Sprouted grain is a luxury for the hen, and beneficial. The young plant, being tender, is eagerly eaten in perference to grass. Build the ponltry house in what you think the most desirable part of the plat. That portion free from grass, to surround the house: on the lawn portion, should be planted small covers of shrubbery about $8 \mathrm{ft}$. square. Four or six of these covers are sufficient, and as hens are poison to any tree or shrub, they should be made of brush. Procure birch or some other brush (birch is best). Cut them when the leares are twothirds grown, they will then adhere to the two's in dying, and last one or two years. Have the body of the brush or min sten one and a half inches in diameter and three fect long; seloct that well corered with brusl, making holes with a small bar eight inches apart and the same in depth to hold them in position. When becoming dilapidated you can place fresh brush on the top, nutil the stands are broken dorn, then renew them in finl. 
Hens or chickens must not be permitted to run on the grass when the dew or rain is upon it. To allow poultry to get wet is one of tire stumbling blocks to success. To avoid this that portion of the yard free from grass should be at the entrance of the house and should be fenced, even then they should not be out when raining. It is indispensable that poultry be not exposed to wet.

The Hev House.-A house suitahle for one hundred hens can be 30 by 20 feet, 7 foot post; the eastern and sonthern exposure to be partly glass. Have the windows so the sum will come in on rising, a tight plank floor, the plank smoothed; no part of the frame except the sills need be over 3 by 5 , and for warmth in winter and coohess in summer have it ceiled or plastered inside. Ceiling is preferable. Let the house inside be free from any obstructions, or what will tempt the hen to perch on any place than that allotted to them, the house to be whitewashed fall and spring.

For ventilation, run a box one foot in the clear under the building, procuring the air pure from the outside; have a small tube of boards four inches in the clear rumning up through the floor from tho main box below, with a valve to be opened and shut as found expeclient. In warm days or when necessary the window can be opened to let any vitiated air pass out. The expense of such a house made of cheap lumber need not be over $\$ 100$. A common, intelligent laborer with a carpenter can do much of the work, lessening the cost. Have the perches on one side of the house fifteen inches apart, ruming lengthways of the house, made of soft wood, two by threo scantling; the broad side to the surface. Place movable supports for them to rest upon. The perches should not be over twelve inches from the floor. Have two sets of perches to be changed weekly, cleansed and aired.

I particularly urge the low perches. Nore hens are killed flying from high perches than all other causes. They will quickly conform to the habit of perching low, if there is no inducement to fly ligher. but if left to themselves they will get as high as they can.

For nests place a row of connected boxes 6 inches deep on the front, 10 inches at the back, with partition every 12 inches, this row of nests can be placed about 14 inches above the back perch. The hens can easily alight in them from the perch. Have a lid or cover ruming the entire length to let down at night, so steep they will not wish to perch on it. If more nests are wanted you can make them in other parts of the house, not over 12 inches from the floor. Inside of the nest shoukd be a braided concaved mat of con'n husks. Have two sets of those mats, that they can be cleaned each alternate week. Straw or hay shonld never be uscd for nests, they will acquive a habit of searching it for secks. procrastinating their stay upon the nest, oftentimes breaking the eggs, from which they will quickly learn to oat, a habit which if onee formed they camnot be broken of. Youlti'y, like everything domesticated, acquire pernicious habits which should be guarded against. 
1 hen at maturity, wiil consume four ounces of fool per day in some form. This inclutes all jartaken of. Their food shonld consist of grain, grass or Jay, regetables, meat, bone, gravel and charcoal, which includes all the articles necessary. Of course, if they rum at large they will eat many other things, and in this connection I will say if properly cared for they will eat greclily uncler other circumstances. As both the egg and flesh will be affected by the food to some extent, more particularly the eggs, it is important that they should be habituated to suitable food. Whoever has the care of hens must be up before the hens. The food eaten at night on going to perch is now digested, and nothing is more rarenous then the hen with an empty crop. They begin to move on the perch uneasily, and as soon as it is day they will alight. It is all important they do noi fret, waiting for their breakfast. This first meal should be soft food. Whole grain will not permeate the system sufficiently quick. This meal should not be prepared the previons night.

Poultry must not be given stale food or vitiated water; thus it will not do to leave food or water in the hennery through the night. The morning meal must be stimulating food. For this meal, take 4 pounds coarse wheat bran to one pound of corn meal, mixed with warm water (if the moming is cold) dissolve one tablespoonful of black or one lialf that of cayeme pepper anct one tablespoonful of salt in boiling water to mix with the feect. One hundrod hens will eat about one pailful at breakfast. Trice a month put the following mixture in the feol, $\frac{1}{2}$ gill to each 100 hens: Receipt, to $\frac{1}{4} \mathrm{lb}$. sulphate of iron and one oz. sulphuric acid, dissolve in 4 rts. of water, see that it is thoroughly incorporated in the feed. After they have eaten their morning meal give them har water to drink and have plenty of water of easy access to them through the day. Be sure the ressels for food or drink are kept clean, and to remove all vessels from the honse at night. The taint of the hennery is injurious. Three hours after brealfast gire them the second meal or lunch, the same as the first meal, also any portion of the first that may be remaining at this time. They will not reguire but about half, as at the morning repast. One will soon learn what is required for a meal and govern himself accordingly. At twolve o clock give a dinner of all the oats they can eat. If any are not consumed let them remain, but you will soon learn what they can eat, and do not practice giving more than they can ent readily. For supper, which should be at time of going on to the perch for night, give all the whole corn they ean eat. Let, oats, barley, or buckwheat be substituted for corn during the short nights--say from first of May mutil the first of September. In regard to this last meal it is desirable the hen should have in her crop during the night what will be retained until morning, as I have before stated, the moment the crop is empty she will begin to be messy. This is to be aroided. Soft feed will not be retained in the crop orcr three hours: the crop filled with oats will last six hours. 
'The same may be said of other' grains excepting corn, which will last 12 hours. I have come at these facts from actual examinations and am thus particular in describing the giving of the feed, simply that the hen may be kept calm and quiet. On this much depends. Corn as a regular food for hens is too heating and should never be fed only as stated, as a retainer during the long nights six or seven months in the year. Another valuable food for hens is tomatoes. For keeping them in a perfectly healthy condition there is noth, ing equal to it.

CARE OF POULTRY IN THE WINTER SEASON.

It is important to get as many eggs in winter as possible, the price being double that in summer. To do this, it is not best to force them to lay in July, Angust or September. This will prepare them for moulting early, and they need a strong vitality at this time, for they have to make an entire new set of quills, at this period. If the hen wishes to set during these months, let her set on artificial eggs as long as she pleases, foreing her to partake of food when she will not do so roluntarily. When thus sitting she will keep in good condition with rery little food. Especial care should be taken she does not get infected with lice. This sitting will be rest for the winter, preparing her for more active work. In the case of hens in winter, I shall be pardoned for repetition. They must not be allowed to leave the house when the snow is on the ground or in winly days. Yon will have in the boxes pulverized charcoal, fine sund, as well as bone and flint stone. Any cobble pornder to the size of corn is suitable; also oyster shells, etc. Hang the beef's head so that when peckect at it will swing. This pleases her, and exercise mentally is as necessary to the hen family as to the human family. By no means must the hen in winter be withont occupation. Not to waste feed, have hoxes one foot wide, two long, and two inches deep, with strips of lath romded and smoothed at the corners, nailed over the top, one inch and a half apart. This not only prevents waste, but filth. Again, remember to remove all boxes at night. Never make use of broken or pounded earthenware; it turns to clay in the crop. Also make no use of prepared lime, either in the shape of old mortar or pure; it dries and parches the crop.

There should be at all times a box of early-cut hay of the best quality before them. This to be cut fine, not over $\frac{1}{4}$ inch-long hay entangles in the crop. Steam the hay if you wish by pouring on boiling water, hut do not permit them to drink this water, it is too astringent. A cabbage heal lnug in the manner of the beef heal is advisable. Heads of wheat or millet, barley or rye can be scattered over the floor in small quantities to ocenpy their. time and keep them excited, or what is better a sheaf of wheat or oats hung like the cabbage head, for them to fly at.

\section{BREED OF HENS.}

From two years' experience with common dung-hill fowls and a great rariety of grades and the few pure bloods before named, I will not decide 


\title{
GATE CITY STONE FILTER CO.
}

\author{
Highest A wards at American Institute. N. Y.. 1885,
} and at all Expositions wherever exhibited.

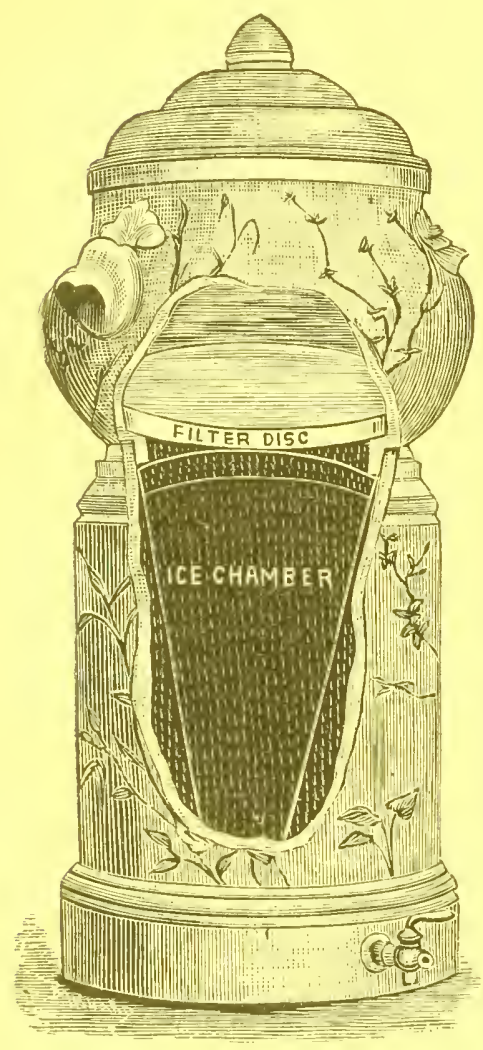

Endorsed by Boards of Health, Sanitary Associations, Physicians and Scientists as the Best, Simplest and most perfect Filter known to the World. Is as easily kept clean as an ordinary Water Pail.

It is the only filter that can be thoroughly cleaned by simply linshing the surface of the filtering stone. The filtering medium being a natural porons stone will last for years, and for families and offices it has no equal. No metal in these filters to poison the water.

Our China Filters are artistically decorated, and regarded as the finest ormament, as well as a filter, that has ever been made. The world has not produced an article of equal worth to the human family. It will remove all sorts of larva or spawn of worms or insects, or strenge loathsome animalculie, or impure floating matter, and renders the water pme, healthy and drinkable.

This cut represents the simple and common sense construction of all our filters. There is nothing of it but a natural stone dise and two jars. No animal charcoal, burnt sponge nor any other compound that retains the filth from zoater where by the least neglect worms are generated; nor is there any combination of Zinc, Iron and Lead to generate active poison.

\section{Union Porcelain Works, Greenpoint, N. Y.}

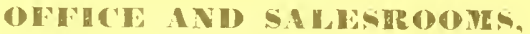

\section{Broadway, and 63 E. 13th Street, New York.}




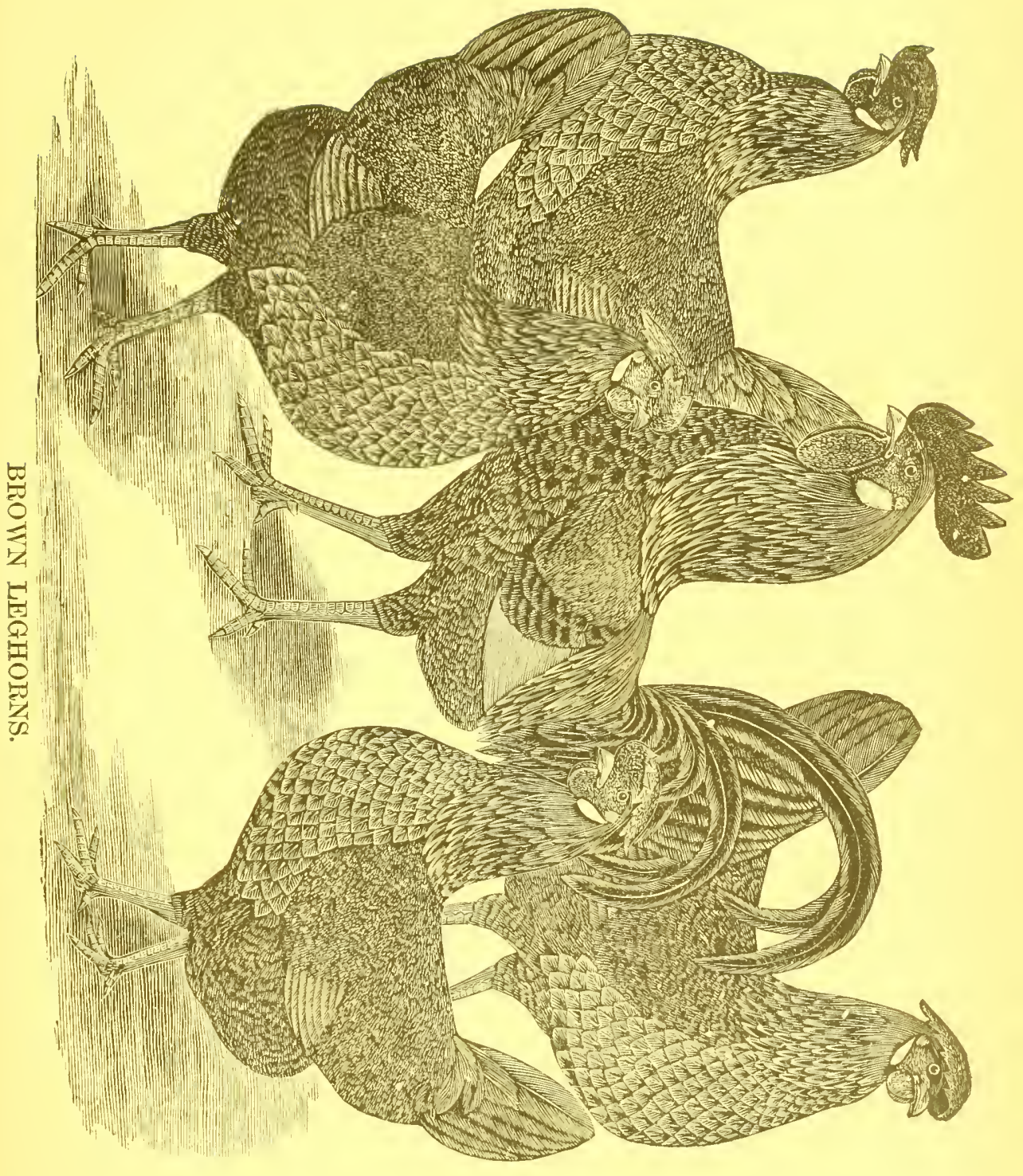


on any special breed; believing as I do that more depends on management than on breeds. Tet the breed is a matter of importance to the practical ponlterer. As a practical worker in the business, I decided on the Brown Leghom for layers and the Light Brahmas for sitting and culinary purposes. I think the Brown Leghorn is more hardy than the White, yet both are equally good layers. I believe if my brood of 140 had been all Leghoms the net profit would have been much increased. She is a business hen who devotes herself to her work. Her pullets, if hatehed in April, or even May, will lay through the winter. The cocks will mature in ninety days fit for broilers, and shonld be disposed of at that age. Neither the male nor female Leghorns are good for the table at a later period. They are much attached to their attendant, are more sensitive and intelligent than any breed I am conversant with; great feeders, laying a rich, solid egg, eight to the pound. The light Brahma is to be preferred to all others for enting when matured, and for a large fowl is extremely delicate and fine flesh, is an excellent hen to set for hatching chicks, on account of its size and warmth of body for brooding. To the negligent manager the particular breed is of no moment. I am inclined to the opinion that blooded fowls are best for all prrposes. I mean pure bred, which I do not think applies to animals: for them I prefer grades, except in swine, which I prefer pure, but always breed with pure bred males; yet old breeds will be improved, and new ones bronght into being in the courses of evolution, for all of which we must thank the fancy breeder and enthusiast in ponltry. I have always noticed that hens of a solid color are the hardiest and best layers, and think the fancy for yellow legs is only fancy. The dunghill has nearly gone ont of existence, and gracles are the poultry of the day. Everyone engaged in the ponltry business (and in has become a business) should read some good special publication mpon the subject. Ascertaining what poultry publications there are in the conntry, procure a eopy of each, and subscribe for the one you think best adapted to your locality. Also, procure standard works on the subject. For these last I prefer English or French authorities, as less smperficial. Tet American works are more progressive and inventive and not as conservative. Yon will read much that is worthless, but you will read much worth retaining. The beginner of limited means will wish to ascertain what knowledge he can obtain before expending much time or money. As before stated, with proper care any breed will pay. Neglected, the farm has no greater curse. All engaged in it as a business will neglect no means of information, actrancing with its progress from year to year. He will have a pride in his occupation, wll not be cliverted by ontside issues, respecting lis work sufficiently to respect himself, ever remembering your respect from other's will be proportionate to your snccess. Enter into the spirit of your occupation. Look on nothing small that has large results. One hundred hens consume abont the same amount of weight in food as 
one cow, and cost about the same amonnt to purchase; no more liable to disease; but if you lose one hen you lose but a fraction of your property. If you lose your cow you lose a hundred hens in ralne. A hundred hens will produce much more manure than one cow. A hen farm will not require as much land, will not deteriorate in quality, while the dairy farm, in lapse of time, will lose its virginity and run to forest. This may not be entirely the fault of the dairy business, but the business has much to do with it. I think the poultry oceupation is calculated to bring to the surface a person's better qualities.

Who can but partake of the spirit of a brood of hens after eating their breakfast? so happy, so noisy, like a bery of school children just set free, and generally more civil. I mean no ill will to the children. They have not had the same watchful care I demand for your hens. But few realize their responsibility, whether hens or children.

In former days the hen would lay but about 50 eggs in the season. now they will prodnce twice that amount. and I claim this last amomnt will be improved upon to that extent, that those engaged will not be satisfied with less than four times the first product. Formerly. a dozen of eggs wonld not weigh as much by 40 per cent. as now; were cheap in summer, in the winter they were not to be hat at any price. Now you have them fresh thronghont the year, are much firmer and richer than formerly. You very quickly notice the difference in a basket of eggs bronght from the bush and those produced near the town where the facilities for progression are greater.

\section{DISEISES OF IIENS.}

The diseases of hens are few, and generally result fatally from inattention at the commencement. Nearly, if not quite all the ailments of poultry arise from colds, improper ventilation, agrravated by bad fool. Rcmp, the effect of colds, is contagious, quickly discorered by a rumning at the eyes and nose. The moment it is noticed the hen shonld be isolated from the flock. If, after a few days, you find no more affected and this one does not improve, kill it. The loss is small and yon may lave saved the flock.

If, on the contrary, you find a nmmber in the same condition, put them by themselves in a warm, lly place, feed them with warm, soft wheat bram and boiled beef. Let them have the water the beef is coolied in for drink, but have it cold. Also, let them lisve cold skimmed milk: no condiments or seasoning, snch as pepper, salt. or other astringents. Feed regularly three times each day, staying hy a few minutes, and if they do not eat remove the food and try again. Be carefnl to remore all droppings when yon feed: permit nothing filthy to be in the room. Never drug poultry. Of all animated life. nothing suffers so much from drugging as ponltry. Pip is cansed by obstructions in the crop, brought on by eating cooker regetables too hot-and they are always too hot-broken earth, which tums to clay, long hay or straw, causing obstructions and made more malignant by eauses 
named in roup. Treatment the same as in roup, with the exception of diet. For food, give wheat or rye in the kernel and cold water for drink.

APOPLEXY.

For this there is, of comse, no cure but a ehange of the evils it arises from, viz., too rich food and flying from high perches; in this case the hen is generally found dead in the nest or on the floor in the morming.

FOUL LEGS.

This is caused by the hen trailing in wet grass, not keeping the house clean from droppings, or by traveling in the soil; the dirt adhering to the leg is cemented by the wet. It is not eontagious, but the same canse that prodnces it in one prodnces it in the entire flock, forming scabs on the legs and feet, producing large protuberances which harbor vermin, ending in unfitting the hen for all practical purposes. It is easily eured by bathing the legs in kerosene morning and evening.

Slipping eggs on the perch is caused by food or water of a relaxing nature. Lard, tallow or fat meat will contribute to this. Fish, when fed in large quantities will taint the egg. I conld not get my hens to eat fish when cared for properly. And now again in reference to meat: if fed to excess, you will diseover fragments of it in the white of the egg. Soft shelled eggs are from some physical derangements, and not from lack of shell-making food. The deformed thick-shelled eggs can be attributed to the same cause. You might as well affirm a cow shonld eat hair, to give her calf a coat, as that the lien should eat crude lime, to give the egg a shell.

Gapes in chickens are caused by worns at the root of the tongue; are easily removed by inserting the tip end of a quill to the nest of worms, thereby scattering them.

TERMIIN.

Another difficulty in the keeping of ponltry is vermin. To most people this seems insmmonntable. I found this the least of all the trouble in the management of ponltry, yet hens will do nothing overrum with vermin. There are two species of ben lice, those infesting the hen day and night, always remaining on them, and those that remain on the perch thronghont the day, feeding on the hen at night, after the manner of bed bugs. Of the two, I think the night prowlers the most pernicions. The hen seems to have no remedy at night: in the day she can wallow in the earth, which she will do. For day lice, hathe at the roots of the tail feathers, also the wing teathers, on top of the head, and muler throat, twice each month. If very bad, twice a week. The night lice can be eradicated by removing the perches and stand each month, supplying their places with a second set. Always have two sets. Another method is to call the hens fiom the honse on a pleasant day and fumigate the house, first making it tight, burning one-half pound of powdered sulphur, placing it in an iron kettle, burning at least one hour. This will suffocate every living thing. Always remember that 
prevention is better than cure in the multiplying of lice as well as in the dis. eases of poultry. A disinfecting egg for nest egg is important. I used one turned from wood, soaked in kerosene. One can be made from sulphur, car. bolic acid and oil of cedar, compressed hard; the properties being brought out by the heat of the hen's body. About this nest egg, have it large like a goose egor a large egg really pleases the hen. It is on the same principle the man permits his hens to get lousy that he lets lis garden be overrun with weeds-shiftlessness-and such a person should have no employment requiring care and thought. In the morning clean up all droppings of the previous night: put them in a barrel away from the hemuery; mix no ashes with them. These droppings, properly managed or sold for their intrinsic value, will pay a good portion of the expense of keeping the flock. Spread under the perches svery day equal bulk of sand or loam as the droppings of the night. Have the floor dry before spreading the loam.

The manure from one hundred hens, mixed with loam or sand as described, will amount to ninety bushels yearly. For cold, wet soil, sand is preferable; if to be used on light, sandy soll. then loam. We ascertained twenty bushels of hen manure to be fully equal to ten cords of cow manure as a fertilizer. It must not come in direct contact with the seed. It would kill the vitality of any seed. It must be considered that the labor of cultivating a crop with the droppings of poultry is much less than with stable droppings, taling in consideration the cost of team work. A hem farm of ten acres, witl 100 hens to the acre, would renovate an exhansted farm of 100 acres in a few years, under competent management.

SALES.

If you have one thonsand or more hens, and I see no reason why the business cammot be extended to thonsands, each hundred being kept by itself, you had better sell your product by contract to the town dealer, You cannot afford to lnckster a lirge amonnt, and it detracts from the diguity of your occupation. Hens should be fitter for market, with exceptional instan ces, the third year, not including the year hatched. The second year will be the most profitable for egors (except in some large varieties). They will begin to decrease in eggs the third year. I will say in this place that very large varieties begin to develope their best laying qualities abont the time the sualler breeds begin to decrease; but large fowls, like large men, are not active workers. Commence selling the hens you intend for market about the first of June. They need not be confined for fattening; dress them in the condition they are in, select the poorest layers first, continumg weokly until the first of September; have them all sold at that time. Chickens will come into the market then, and scarcely any one will buy old heus when chickens can be procmed. After disposing of the hens, confine separately in a yard what young roosters you have not sold earlier for broilers, which, if you have consulted your own interest will be few, and sell before cold weather, 
when they are transported from a distance. Tou need not shut your poultry up in a dark place to fat them, neither should young roosters be allowed to run with hens at the expiration of sixty days from birth.

In dressing poultry so as not to tear the skin, dip them in cold water.Have a barrel of cold water at hand, and on taking off the head plunge them in the water, holding them with the hand until they cease fluttering, and on taking them out the feathers will readily come oft, learing the skin smooth, not puffing it as when sealded, and being much more readily sold under the former method. Let the entrails remain until the forrl is cold, then they can be extracted much cleaner. Remore the crop when you do the entrails. Then hang in a dry place where the air can circulate through them, and they will be better for cooking at the expiration of a week, than when first lilled. If your chickens are not permitted to pereh young, and your perehes are three inches wide, you will have no deformed or crooked breast-bones; No one should risk lis reputation by sending a bad or second-rate article to market. Another method of plucking the feather's from fowls is to tie them up by the legs, inserting a small knife through the neck, separating the rertebra; while in the death throes the feathers will all scrape off. There is nothing inhuman in this method, the bird being oblivious to pain upon the separation of the rertebri.

BREEDING CHICKENS.

Before entering upon this subjeet I must say a few words upon domestication-I might say civilization-of the hen. A few Indians roam over large territories to procure food sufficient for sustaining life, while cirilized man wants but little land to supply his wants. Five acres deroted to poultry, under skillful management, will supply a family of six with all their wants and many of the luxuries of life. A single brood of partridges will fly over a thousand-acre forest to find enough to eat. But one hundred hens can be supported on one acre of land.

The hen must be thoroughly domesticated to be of practical value. This domestication is produced by your familiarity with her; learning all her peculiarities, she in the meantime learning yours; adapting yourselves to each other, with this difference: you will make her think she has her own way, when, in reality, she does not. We do not advise setting over nine eggs under the hen; if the hen is small, seven are sufficient. Our reasons for this are that the chicks will come out with stronger vitality, this vitality improving as they grow older, from good brooding. A good foundation from the start in everything, means the after success. The young chicks will appear at the end of twenty-one days. As soon as the young chicken lifts its head up in the downy feathers of the mother, the lice gathered during the setting will go for the young and tender chicken's head. This should be at tended to immediately; a couple of drops of kerosene oil or camphor will drive them away. The first week chickens should be fed on hard-boiled 
eggs, sufficiently hard to crumble, and with corn bread, baked so hard you can granulate it. After the first week omit the eggs entirely, having shallow boxes of food for them to go to at will. For food, have the crumbled corn bread, granulated beef scraps, bone and oyster shells, sour milk, with plenty of fresh water always at their command. When thirty days old, omit the corn bread, feeding corn-meal mixed with slim milk, diluted with water; also at this time give them wheat screenings, which contain various kinds of seeds, giving them the same care as regards cleanliness as you do your laying hens. The chicken should not go on to the perch before the age of three months, and the mother should be the judge as to time of weaning.

Let the hen with chickens be cooped the first four weeks; she will brood the chickens much more. Care should be taken to move the coops every altermate day. Also keep the brooding hens and chickens separate from the laying hens. To break a hen from setting, confine her in an open coop where she can see the other hens, and she will soon begin to sing, when she can be set at large.

We have refrained from saying anything in regard to incubators, simply from the fact that we have no practical knowledge of them, other than witnessing their operations at the Madison Square Garden exhibitions in New York. That they perform the work assigned to them well is unquestionable. To us the only objection seems the after brooding. But we are assured by those using them that the artificial brooding is equal to the brooding of the mother. Presuming this to be so, then, for extensive operations, they would be advantageous as well as economical. They are extensively used about New York City for rearing early chickens to supply that market.

CONFINING POULTRY

Hens will not fly over any fence without first alighting on the top. Hence the fence should have no resting place there. A picket fence 3 or $4 \mathrm{ft}$. high will keep them in their limits. Should there be an unruly one, dispose of it before it contaminates the flock.

A very good, cheap and efficient fence can be made from birch brush, such as mentioned for covers in a former part of this work. A man can make 100 feet per day of this kind of fence, interlacing the slender twigs at the bottom, the branches projecting upward from the top. They will not attempt to rest upon them. Hens are never known to alight on the slender limbs of a tree. as birds will. A wire netting 18 inches high for the foundation fence, with the twigs of birches interlacing the meshes, projecting upward makes a good, cheap and durable fence, with occasional repairing; it also pleases the hens.

A family in the city can keep a bevy of a dozen hens to advantage in a back yard of 300 square feet. They will be very productive, creating no filth or vermin if you follow the details laid down; but unless one feels an 
interest in poultry, he should not attemptit. In the city you should not raise chickens, but the liens properly managed will keep you in fresh eggs.

The average farmer will speak depreciatingly of keeping hens. His only idea of the business is a flock running at large over his premises, making: everything filthy they come in contact with, scratching his garden in the spring and his grain as soon as housed in the fall. He cannot tell what number he has; weitler cares. He gets an egg if he can find the nest, and some chickens for Thanksgiving if he can catch them. They are as antagonistic to him as he to them. Could he come to see the importance of this business, he would appreciate it.

We intended saying, when speaking of chickens in another part of this book, that it is not advisable to hatch them after the first of May, if you wish for pullets to lay the following winter. If hatched early they will lay the first winter, presuming the rules are followed as mentioned for breeding.

As no poultry moult the first season, the earlier they are hatched in the Spring the sooner will they moult the succeeding season. When moulting you will feed freely corn, sun-flower seed, buckwhent, meat, or any rich food, withont regard to their laying eggs, but change the feed when through moulting.

In regard to the one-acre yard and single poultry house I occupied for my hens. This, I think, could be subdivided into four yards, with twenty-five hens in each, or eight yirds with twelve hens each, with henneries proportionately arranged, requiring but little more work in the case, and perhaps enhancing the product. We also think a well-ventilated open basement or cellar might produce more eggs in winter.

Clickens hatched in March and April should have a fire in the room they rum in if there is any dauger of being chilled. Care is very neccessary with chickens bronglit out this early to keep them improving:

We must apologize to the reader for omitting to make mention of the many different breeds of poultry. As reporter for the Anerican Darrinan we have attended the numerous poultry exhibitions in Madison Square Garden, New Tork, but have seen nothing to change onr opinion as to the special breeds to lieep from those named in the earlier part of this work. Of over fifty different breeds, those we should desire to experiment with,or rather those we thomght of the unost practical value, were Plymonth Rock, Wyandottes, Dominiques, Audalusians, Fondans and Dorlings. It is for those engaged in the business to exercise their own good seuse and judgment in the prosecution of their work, never forgetting that minor details are not to be lost sight of.

It is said by most agricultural journals, poultry keeping, to be lnerative, must be confined to small numbers: but it is to be remembered that special agricultural paper's are simply reflectors of public sentiment among farmers, often made up of contributions from those who theorize without practice. 
A young man of my acquaintance in Windham County, Connecticut, on being married, purchased ten acres of land, leasing a small cottage adjoining. $\mathrm{He}$, with the assistance of his wife, commenced the poultry business, divicling his land into ten lots of one acre each, having on each all the appurtenances for keeping 100 hens. At the time of visiting his place he had been five year's in the occupation, keeping a minute account of expenses and income. Cheerfully showing me his books, we found his annual profits were one dollar and forty-five cents per hen above all cost excepting the labor of himself and wife, six hours at different periods of the day, but it was light work. We could not but contrast the contented cheerfulness of this couple with a couple in an adjoining town in the same county possessing 400 acres of land, yet unable to get a living; but, nevertheless, view. ing with contempt the hen business of $\mathrm{Mr}$. M-_- and his estimable wife.

The public have been made familiar with the enterprise of Mr. Hawkins through the numerous poultry exhibitions at Madison Square Garden. Mr. Hawkins has a very successful poultry farm in Lancaster, Worcester County, Mass., keeping six thonsand, in the gross, of special breeds, shipping them over the country, and through this employment has acquired a competence, also proving the fact that large numbers can be kept on the same farm.

France leads the world in its production of poultry and eggs. She lras immense numbers of small farmers, proprietors or lease holders, who raise poultry and eggs for exportation to London and other large places on the continent. Her people enjoy that supreme contentment and pleasure which can only be derived from working the soil under the broad canopy of heaven, having no more land than they $\mathrm{cm}$ work themselves withont orerworking, having plenty of time to educate their children, forming and molding their infant minds in such a manner that an impression is left which can nerer be effaced. Such are the attachments of the French people to home, they have no desire to emigrate. Her capitalists learned a lesson in the revolution of 1793. She learned in that and succeeding social convulsions, that there is a limit to the endurance of man.

One last word to the mothers and children of the rural sections. In $\mathbf{1 8 5 3}$ the poultry product of this country amounted to five hundred and sixty millions of dollars. It was double the value of the dairy product and more than donble the value of the cotton crop. For this immense product the country is indebted almost entirely to yon. But you are not credited; do not even know the fact yourselves, your products flow from every hillside and valley. Shall the children of farmers have a fair showing at home, or shall they be forced to accept of employment as factory operatives, shopgirls or saleswomen, etc? Te have never yet seen the girl who would desert home and home associations if home was made desirable and an opportunity given to advance herself there. 
One more word to the wives and daughters of farmers, from one who knows full well the trammels of their suroundings. To you the country is in debt for its poultry and eggs. Without realizing the fact, you are driven to this work from sheer necessity for means to supply the many thirgs you need and onght to have. At the present day the linsband and father is battling ngainst the head-tide of monopoly in producing corn, wheat, beef and pork. He has become unconsciously an aristocuatic pauper. Should he have a dollar extra above his wants he sinks it in a savings bank to be drawn by the capitalist to corner wheat, or build up the city-money he should use to beantify his own home and surroundings.

And now one word to farmers from one who is of them. The rules that governed youx fathers in their generation. are not the rules to govern you in your generation. It was as impossible for them to know what your wants might be as it would be for you in your manhood to wear the swaddling clothes of your infancy. If you can see where your parents erred in your early training, see to it you do not commit the error in the training of your boys. Give them some inducement to stay at home; take no advantage of your legal right to twenty-one years, but let them have the freedom that will make home desirable. Be a boy in your manhood, making a man of them in their boyhood. One word to the boys and girls, and we have done. We would not take from youth one jot or tittle of its joyousness. We can be young but once; the morning is fresh the evening is weary. We wish you to find real amusement in what will conduce to your mental and material comfort. The two are inseparable. Never wish for what you don't need, because some of your mates possess it. Cultivate a taste for reading, and all sides of a question; avoid as much as possible all prejudice; cultivate candor and charity; inform yourselves of the world you know and see. In your pursuit for knowledge travel the highway of science; get familar with geology-you should know what the soil is formed of; astronomy-you should learn something of the heavens you hear so much about; chemistry-it is necessary in these days of adulteration; botany-that you may know about plants as well as see them; geography-yon learn the earth's surface without traveling. All these studies lead you to think, give you an inguiring mind; make you nobler, purer, better.

GEESE.

The common goose was found domesticated as far back as when Cresar first came to Britain, and has been a popular fowl for the table, its feathers for beds and its quills for writing ever since. We well remember when no other pen was in use but the pen made from the goose-quill.

The wild goose of America, which migrates from north to south, is a very handsome bixd, and will thrive and breed well in a domesticated state; is good for the table, and in all respects, we think, equal to the domesticated goose of Europe under like treatment. 
Its head, two-thirds of the neck, the large quills, rump and tail are black, the back and wings are a light brown, the base of the neck and the under plumage pale gray or white. There are a few white feather's about the eye. A white cravat of a kidney shape forms a conspicnons mark on the throat, the bill and feet are black. The above description of the wild goose we jotted down while viewing a domesticated wild goose in Central Park.

When domesticated it ceases to be so strictly monogamous as in a wild state.

The wild geese migrate in the spring north, returning in the fall to their winter quarters. When they commence their journey from the south nor thward early, the farmer knows spring will open early; if they commence their return early in the fall, he knows the winter is nigh. Some years they begin to migrate as early as the 15 th of March, and to return as late as the 1 st of November. Other years their migrations may be three weeks later or earlier. Their instinct in this respect is truly phenomenal. They fly in the shape of the letter $\mathrm{A}$, witl a leader, in flocks of from thirty to one hundred, making a very discordant noise as they pass. If the atmosphere is hazy they will fly low, often within reach of the sportsman's rifle, and sometimes one is brought to the earth. They never fly orer cities or villages unless lost in the fog. Wre recollect the leader of a flock of about fifty being shot, when the entire flock became so demoralized they turned about in their course, alighting on a small pond in the vicinity, seemingly stupefied, and were all captured in a few days.

The following season some lilies, of a bright red color, but in other respects like the white lily, were found growing in this pond; the seed were supposed to have been deposited by the geese. It is be regreted that they were afterward destroyed by curiosity-mongers. Wild geese are exceedingly fond of cranberries, and scatter these and other seeds in going over the country, which, if congenial to the soil and climate, take root and become indigenous to the country.

In a good pasture geese will nearly get their living. Turning their head sidewise, they nip the grass off quite close and consume a good quantity. The idea that nothing will feed after geese arises from the fact that nothing can feed after them. They nip the grass so close that none remains until time restores its growth. Different flocks of geese will keep distinct, and a good feed of corn at roosting time will keep up the wish and willingness to return home at night. The feathers have a ligh market value, and are taken from the geese to save their loss at moulting time. At that time, the skin round the shaft of the old feathers shrivels for want of nourishment, the moulting feathers come away with a touch, and the poultry woman takes only tnose that are ready to fall. If this process is not managed with the greatest care and tenderness, it may be revoltingly cruel; but if it be confined to the removal of the moulting feathers, it is less so than the goose-plucking we often 
hear of. The goose house or shed need not be entirely closed. The roof should be tight, so as not to let in the rain, and care shonld be taken to perchde the cold winds on the geese at night. The floor should be dry and the straw should be removed as often as cleanliness requires. and always liept diry.

Geese are essentially vegetable feeders; they will eat any lind of grain, any good quality of grass or any sort of garden vegetation. They are clean feeders, and will not tonch offal or animal food of any kind. If the geese can have a pond at command within the day's range, so much the better; but they can do without it. The old geese require a little corn twice a day-a mere sprinkle in the morning if they have the opportunity of doing much for themselves, and a good feed at night. It is a good thing to feed the breeding-stock well in the winter, to promote early laying and sitting, for the chance of the goose prodneing a second brood the same year. At the beginning of the breeting season feer freely plenty of boiled barley, corn, wheat, or any lind of meal.

In mild seasons the goose will lay early. She should have a good, large nest in a secure, quiet corner. She can cover about flfteen eggs at a sitting, which takes thirty days. See that plenty of food and water are at hand for her when she leaves the nest. She is a patient, good sitter and a good mother. It is mnnecessary to separate her from the gander when she sits, as he will take an interest in her work and be as good a father to the goslings as she is a mother.

The gander quite assumes his monogamous habits when the goose sits and hatches, devotes himself to her entirely and puts forth his no small degree of strength and vigilance in her defense and that of her little ones. He is so good a defender that there is no better plan than to put the brood and their parents into an inclosme together. The goose will not be interfered with while she is hatching. If any attempt to meddle be made, she only injures her brood intending to defend them.

The little ones may be fed on corn or wheat meal, with some cooling green food chopped up with it, such as grass, parsley, etc. After a few weeks you can feed any variety of meal with eaution.

At first they should not be put out in the morning until the grass is dry, and they should be housed early at night with a good bed of clean straw. They are reared with little care or trouble, but where they have their ranges wild hemlock and poisonous night-shade should be destroyed. What is known among children in the comntry as the pollywog is sure death to the goslings; the old hirds are too wise to eat them. The young birds should never bo allowerl to fall off in condition. but kept up by constant good feeding milil wanted for the table or marliet. They can searcely be too highly fed if large size is desired. 
For breeding, allow three geese to a gander. Let them be of mature age, and they will do well up to twenty years. If the season is early, they will lay early in March, except in the Northern latitucle where it will be a little, later. They usually lay every other day, and if the eggs are left they will want to sit when they have about twelve or fifteen: but if they are removed they will often lay a great number. They will sit twice a year, and occasionally three times.

In contradiction to the saying that nothing will eat after geese, it is well known that their manure is excellent for improving the grass of coarse meadow lands, and that cows relish the feed. It is a very powerful manure, and is needed in but moderate quantities. When young geese are penned "up to fatten, from six to ten will do better together thin a smaller number. Feed them for a couple of weeks on corn in water, and finish their fattening with meal. The house or inclosure in which they are put should be kept quiet, dry, warm and rather dark. Before the time for their being lilled, if they are allowed to go in the water, they will be picked more easily, and the feathers be better and cleaner.

We give the following account of a goose farm in Mansfield, Bristol Comnty Massachusetts, by George A. Stockwell and published in the Agricultural Revien: (scotloml).

\section{A Goose Farm.}

By George A. Stochinel.

In a town of Mansfield. State of Massachusetts, is a goose farm- a farm of sixty acres on which geese and ducks are fattened for market. As the number of geese is larger than that of the ducks, the farm is, in trutl, a goose farm. Abont twenty years ago, Mr. G. F. Anstin, since associated with his son, Mr. C. M. Anstin, began to deal in green geese, buying the goslings in spring, and hurrying them toward market plumpness as speedily as corn and meal could make the transformation. The business has added to itself until sixty acres in not enough, and other and larger fields must be found.

In April or the latter part of March, the goslings begin to arrive. They are then three weels or a month old, and were hatched in sonthern Rhode Island, the greater number coming from Tiverton and Little Compton, and the region round abont. They have ample room for growth, and their appetites are ministered to with care and regularity. The gosling is a hearty eater, enjoys his dimner every half hour, if he can get it: has no digestion troubles, and hence adds fit and tender muscle quickly, In this great goose mill, the fledgling, the wingless gosling becomes a green goose in a few weeks, perhaps not fully grown, bat worth more per pound in the green state than when the ripeness of full maturity is upon him. 
Accordingly, the young geese begin to move toward market a few weeks after they arrive, to take their places, a new and later crop comes to the farm. The goslings arrive mp to September and October, the later hatched goslings coming from Canada. In the early history of the business, the proprietor went to Canada, and bonght, personally, all the goslings he conld find. Later, an agent on the gromel collects the goslings, arranging with the inhabitants in eertain towns to rear and sell.

No attention is paid to the breed of geese. All the proprietor wants is a goose-frame, and he will be responsille for its filling out. The flocks contain, apparently, every known hybrid. There are individual specimens that appear to be pure Tonlonse, and brown and China geese. From Canata come many "mongrels." The mongrel is a cross between the wild and tame goose, and, strange as it may appear, the mongrels are all mules. The geese lay, but there is no germ of life in the egg, from which it may be inferred that the wild goose is not a goose, but belongs to some other species of aquatic fowls.

During the season 20,000 goslings came, and departed as geese. At one time this year, there were on the farm 13.000 geese and 7.000 ducks all in good spirits, and all singing their little song. Imagine 13,000 goose-screams combined and added to the total sum of 7.000 dnck-quacks. To the untutored ear there is music in it, but the man who deals ont the food, and is with the geese and ducks constantly, exclaims, "Noise? 'I don't hear anything!" No, he doesn't hear anything, for the same reason that an operative in the room with a hundred looms going at full speed, does not hear anything.

At this time of the year (near Christmas) the stock grows light, and by the first of January, or soon after, the last goose has gone, and the goose machinery rests for two or three months. When the writer visited this goose ranch, only about 4,000 geese remained, and of this number 2,000 were in one flock. Did yon ever see 2,000 geese together? The sight is worth a five-mile walk-just what the writer paid. The members of the flock appear to be governed by a common impulse. Now, all, or the greater ummber, sit down, and thrust the bill under a wing (the day was cold), now they stand up on one leg, drawing up the other to warm it, and now they have important business at the other end of the pastmre, and away they go, stretching and craning their necks, sone flying, and all running, and all making much talk about it. They rest awhile, and then come back in the same hilarious manner. The 2,000 came late, and are allowed to run, but before slaughter they will be kept in small pens where they camnot race and run, and where they can only eat and drink and grow fat. In twenty pens were groups of geese undergoing the final process-the process of adding the triple or cuadruple plate of fat. From these pens they go to the coops, where they remain un- 
til "empty" (they are not chawn), and then are delivered in turn to the executioner, the picker, the washer and dresser, and to the packer.

That do they eat? Scalled meal is the steady diet, fecl twice a clay, and whole corn once a day, three meals regular, and green stuff in its season, between. The arerage amount of grain per clay fed during the nine months is thirty-six bushels. The cook and waiter has been in service sir years. A kettle holding ninety gallons is filled with water, and the water brought to the boiling point. In a large trough near are seven bushels of meal, and to this is added the ninety gallons of water. He mixes with a shovel, and when cooled transfers to trays on a wheelbarrow. In summer the food is given cold; in winter warm, but not hot. As soon as one"batch" is ready another is prepared. When the eaters are more numerous, the cook can be cook only, and another man waits on the goose tables. When con is fed to the big flock, a man takes a bag on his shoulder, and holding the mouth of the bag, lets the corn run out as he walks. Then may be heard the rustle of corn domn two thousand goose necks. The scaldecl meal is placed in troughs or shallow boxes, and a supply is at hand all the time. At the first meal in the morning there is a general clamor, and every one of the two thonsand demands instant relief from the pangs of hunger. If food be present the goose appear's to be linngry every ten minutes, and helps himself.

In the goose pens and pastures there is nothing grown except the geese, they have eaten, root and branch, everything that dared to grow, whether mullens, thistle or srass. Abont thirty acres of green stuff was raised for the geese. The oats were cut green, and withont any further cutting were dealt ont as to cattle. Corn was raised for the same purpose, and fed standing. When the corn was in the milk the geese were tumed in. They ate the com, the cob, the stalk, leaves, everything above ground, and then pulled up the roots. Nothing was left to indicate that a corn field had been there.

The farm plant consists of about a dozen different buildings, with a windmill in the centre for pumping water. As the geese and ducks do not have access to natural water sources, water must be supplied, and this is a work of some magnitude, for no animal is so continually thirsty as a goose or duck. There must be abundance for drinking, and for ducks at least enough for bathing. The duck must have also mud, simply mud, a place where the water stands and softens the earth. A duck on sandy soil, where the rain lisappears as fast as it falls, will not thrive. although sufficient water may be supplied for drinking purposes.

Abont thirty men are employed thronglont the nine months. In the busy season seventeen pickers or plnckers find enongh to ilo. Each picker can "strip" forty geese in a day, but he must hurry, and has no time to spin yarns or to exchange gossip with his fellow pickers. At the present time, early part of December, two hundred and fifty geese a day are prepared for 
market, and abont eight hundred chickens, not raised on the place, are dressed every week. These are drawn, but all the geese are sent to market undrawn.

The raising of geese, or any other kind of poultry, is not difficult. They raise themselves if fool and proper care be present, but it is not always easy to find a market at good prices for large quantities. The proprietors of this goose farm have a store in Boston near the Quincy market as a distribut ing depot for Boston and the East, but for the West and South, shipments are made from the farm to three great markets, New York, Brooklyn and Philadelphia. A dealer in Fulton market, New York, has ordered two thousand geese for the holiday trade. The demand exceeds the supply.

It is believed, or it has been said by some agriculturists, that the excreta of geese was useless as a fertilizer. Let this fact stand against the statement. The goose farm has become so enriched by the presence of the geese, that the proprietors do not dare to use it longer, fearing it may be unhealthful. Therefore, next spring, a farm of sixty acres, new land, near the present farm, will be used for pasture, while the old farm will be devoted to crops of forage, which will grow upon it luxuriantly. In a few years the geese will come back and the other farm will be cultivated.-Agricultural Review (Scotland).

\section{DUCKS.}

Ducks are very hardy, easy to rear, and easy to feed as regards quality of food. They will eat almost anything with appetite and relish. As regards quantity, they are less easily satisfied, being lecidedly great comsumers. They will with tolerably free range, to much towards their own lieeping, foraging industriously on land and water.

Feeding twice a day, morning and night, is quite enough for the old ducks, if they have liberty. Oats are the best feed for giving firmness of flesh, and they are best thrown in water for them. A medley male of all kinds of refuse vegetables and other kitchen scraps, with a little meal, is good as a portion of their liet: they will eat boiled vegetables of all kinds with especial relish. They help largely towards their own keep if they have the opportunity, by eating all kinds of small reptiles and insects in great quantities. They are useful in the garden for destroying insects, providing it is at a time of the year when the hard flattening down of their tread is not injurious to the plants. They will eat filth and garbage, but this should be kept from those intended for cooking.

A shed with a water-tight roof and dry ground floor is sufficient house. If the floor is damp, they are apt to break the eggs. However quiet the setter may be, there shonld be convenience for shutting them in at night, as the laying time approaches-about the first of April; if the season is early, the first of March. If they are shut in every night at this time, they will form the habit of laying their eggs in a nest, as they lay early in the morn- 
ing. They are very wandering layers, if no precantion is talien, dropping their eggs abont, even in the water. The appearance of weight behind, swimming with their tail flat on the water, are indications that the time of laying is near. The nest can be made of straw, on the ground; shntting them up from intrusion while sitting, except at feeding time.

Ducks begin to lay early, and are generally good layers; will often continue to lay until commencing to moult. They do best with the use of a pond, but will thrive with a small tank, if kept well supplied. Four ducks to a drake is sufficient. They are too greedy, dirty and sloppy for other kinds of poultry to be kept with them. It is a mistake to rol, the duck of her privilege to set and rear her own little ones, for two reasons : 1st. When judiciously placed, not r.nnecessarily interfered with during setting, or circumscribed in her ramblings with her little ones, she is a good mother, as she was a good sitter. Rearing by a hen seems to bear ont the old game fowl breeder's idea of the sitter's influence on the brood she latches and rears. We think all poultry, to be prosperous, should be reared by its kind In addition, as the duck is an affectionate mother caring for the wellheing of her brood, there is no reason why she should be denied the lot miversally coveted by all living animals-maternity.

The duck makes lnown her wish to sit by keeping to the nest prerseveringly, and shows her intention not to be interfered with pretty evidently by bestowing a good peck witl her hard, broad bill on any hand that approaches. She so much objects to interference, that in hers, as in all similar cases, it is best to let her alone. When positively necessary to remove the eggs take her up and set her down on the ontside of the door while the requisite attention to the exgs or duckling goes on.

For a good-sized duck, from ten to twelve eggs nre sufficient for a sittiug. Give her com near her nest, and water convenient, that she may come off and feed when she wishes. It will also do her good to bathe in the water, imparting that warm moisture to the eggs which is favorable to inculuation. If the duck is a quiet one. the duckling's may be left with her as she hatches. When yon think some of the little ones have been hatched a good many honrs, some corn meal mixed with skim milk or warm water shonld be placed before the duck. She will soon teach the little one to eat. When she shows a wish to lead them ont, she may be pemned on the grass if the weather is warm and dry ; otherwise, in a shed.

'Two or more ducks may be penned together with their young, as they never quarrel. For the first few weeks it is best the little ones hare no water to immerse themselves in. It is not hest to wot the down at that age. The mother should have a tub for bathing herself: a small mug for the little ones to drink from, fastened so as not to tum over, and too sinall to get into. They can then bathe and wash their breasts, but camnot wet the down about the abdomen. Their supply of water should be often renewed. 
Ducks, old and young, should have a good bed of straw, or anything that is dry will do. 'The eggs do not keep as well as hens' eggs, and should be set fresh.

The fattening of duclis is no difficult matter, they are so willing to aid in the work themselves. They will fatten at large with extra supplies of food, or they may be shut up for the purpose. Corn meal, cracked corn, or indeed any variety of meal will answer the purpose of fattening. Nothing fattens so easily as the duck. We give the names of the breeds of ducks which we should select to breed from: Aylesbury and Ronen: these are the only breeds we hare had experience with. Any one living near a small pond can make the breeding of ducks exceedingly profitable. Wild ducks are common all orer the country. We are familiar with them on our native river; have found their eggs, set them under a hen, scarcely ever failing to hatch them. They will fly away the first opportmity in the fall. which is the best part of the business. They are small and ill-flavored when cooked: and if it can be called sport to lumt and kill the most harmless of all birds living, then that must be their redeeming virtue. But one must get nearer to them than we ever could to shoot them on a river. On a pond or lake they can be shot as they rise. They fly in a single line, like Indians on the warpath.

TURKEYS.

When America was first discovered the wild turkey, among other hitherto runknown birds, was found. It has now been under domestication for so long a period that the wild seems almost a distinct race. The wild is fast disappearing. It was formerly plentiful from Maine to California. It was migratory, keeping in flocks, yet irregular, without the systematic order pertaining to wild geese. In antumn the gobblers would congregate in flocks of ten to one humdred, seeking their food apart from the hens, who still kept with their broods. The season of courtship would commence about the first of March. In April the hen would arrange her rude nest, which was generally a collection of withered leaves well concealed by brush-wood, several hens often laying in the same nest, always keeping them well covered with dry leaves. The wild hen lays but one litter of eggs in the season and will choose dry, undulating ground as a range for her brood; yet, in a dry season, the stock of wild turkeys are much more plentiful than in a wet season, which is an evidence that the wild cannot endure damp more than the domesticated. At about two weeks old they begin to roost on branches of trees still brooded by their mother. Their food is strawberries and other wild berries, grass-hoppers and other insects. By tine month of August the young birds use their wings and legs vigorously, congregating in companies of several broods together until after the October migration, when the males separate from the females. For the foregoing description of the wild turkey I am indebted to a former resident of North Carolina 
The old birds among our domestic turkeys are extremely hardy, not sub: ject to disease, requiring but little care beyond feeding, shelter from rain and a good range. The young are extremely tender, requiring constant attention to make them prosper. There is a wonderful difference in temper and disposition between the male and female turkey. The cock is arrogant, ireful and implacable. The hen is gentle, good-tempered and good to her little ones, sometimes treading on them from her awkwardness.

Turkeys do not attain full growth and maturity until they moult after they are two years old, and for this reason should not breed until after that period if you wish for first-class birds. The hen should sit on the first litter of eggs she lays in the season, that they may have the best of the year to make their growth. The cock is generally spiteful to the hen and their young ones, and is not necessarily needed after the early part of the season, and the eggs of the hen are fertilized. The entire clutch of eggs are fertilized at the first intercourse. One turkey cock can serve for an entire neighborhood. He is in his prime from three to seven years, or even ten years. In breeding turkeys, more than any other fowls, first-class birds should be selected. Their plumage should be black; yet russet is not undesirable; but never breed from white plumage. In the domestication of turkeys, the hen should be watched when about to make her nest, and with a little humoring, will make it where you desire. Make her a good solid bed of straw and dry leaves in a snug, secluded spot, giving her a nest egg. When she seems anxions to lay shut her in until the egg is laid, and for the first two or three times, after which she will lieep constant on the nest. Remove the eggs as they are laid, only leaving the nest egg. Keep them in a dry place of medium temperature until she wants to set, when they should be placed carefully under her. She is a steady setter; will scarcely leave her nest to take necessary food, and should be lifted off for that purpose if going too long a time. The person she is familiar with should attend her. She should never be disturbed by others, or meddled with unless breakage or any other unfortunate accident makes it necessary to arrange the nest. Presuming all to be right, the young ean be looked for in twenty-eight or twenty-nine days. If she has been a nice quiet setter, leave her young with her, only removing the empty shells, but if she has been fidgetty, remove them, keeping them warm until all are hatched, but the mother warmth is best when she can be trusted. The domesticated bird will sometimes lay and hatch a second brood, but it is not desirable: they require too much care, and are never hardy, contending with the chilly mornings and cold nights of Autumn. The young turkeys are extremely Gelicate, and this continnes throngh the first six weeks; until then they must not be neglected. At first the little ones should be fed on hard boiled eggs, chopped fine, mixed with breat crumbs, young onion tops, lettuce, nettle and parsley. Give their water in shallow pans to avoid wetting the down. As they get older feed corn meal boiled in milk, cracked corn and milk curd. They 
manst be constantly well fel from the first. so as to never lose condition : for if they once get poor they can never be restored. The most important thing of all is to never let the little turkeys get wet or damp. Keep them in in the morning 'till the dew is off the grass, put them up before the damp of the even. ing, and never let them ont in the rain. Farmers wives rear turkeys success fully by strictly obeying the above rinles.

The young cocks shoot the red about nine weeks from hatching. This is a critical time, and they will require rich and nutritions food, which should be contimed. They must be kept plump and never allowed to shrink until ready for their destination. The turkey will not fat perfectly until matured. Even the few weeks intervening between Thanksgiving and Christmas show the superiority of the latter, The most perfect turkey for the table is the hen who has lived over one season and brought up her brood. Cramming turkeys to fatten them is moch practiced. We hardly see the necessity for this process, if the turkey has plenty of good feed mixed with skim milk sweetened with cheap molasses.

Turkeys will make a fast and great growth getting extremely fat if the season is what is termed a grasshopper year. Grasshoppers seem to be the natural food of the turkeys. We have never known but one turkey in our loug experience to be puny, and that was a late-hatched one and we must consider them the hardiest of all the poultry after getting beyond the ten weeks named, when the males show the red.

The turkey is a peculiar bird in some respects. In driving them they will not rum under a fence, are always looking up, yet alone by themselves will quickly discover any loop-hole. Sixty years ago speculator's in Vermont wonld buy large droves of turkeys of many thousands, driving them on the road to Boston maiket like cattle, a team leading them scattering corn on the way, encleavoring to be near trees before nightfall. Early in the morning they would come at call to pursue their journey. A peculiarity of the hen turkey is she will set continuously for a long period, if the young are removed from her as they are hatched and fresh eggs placed under her. We have known of their setting three months and their setting six months voluntarily has been affirmer. When sitting in this manner they become very fat, consuming scarcely any food. Every farmer should certainly raise at least a dozen of turkeys for lis own table. It is this thoughtfulness about little things that leaves an inclelible impression on the family circle. 


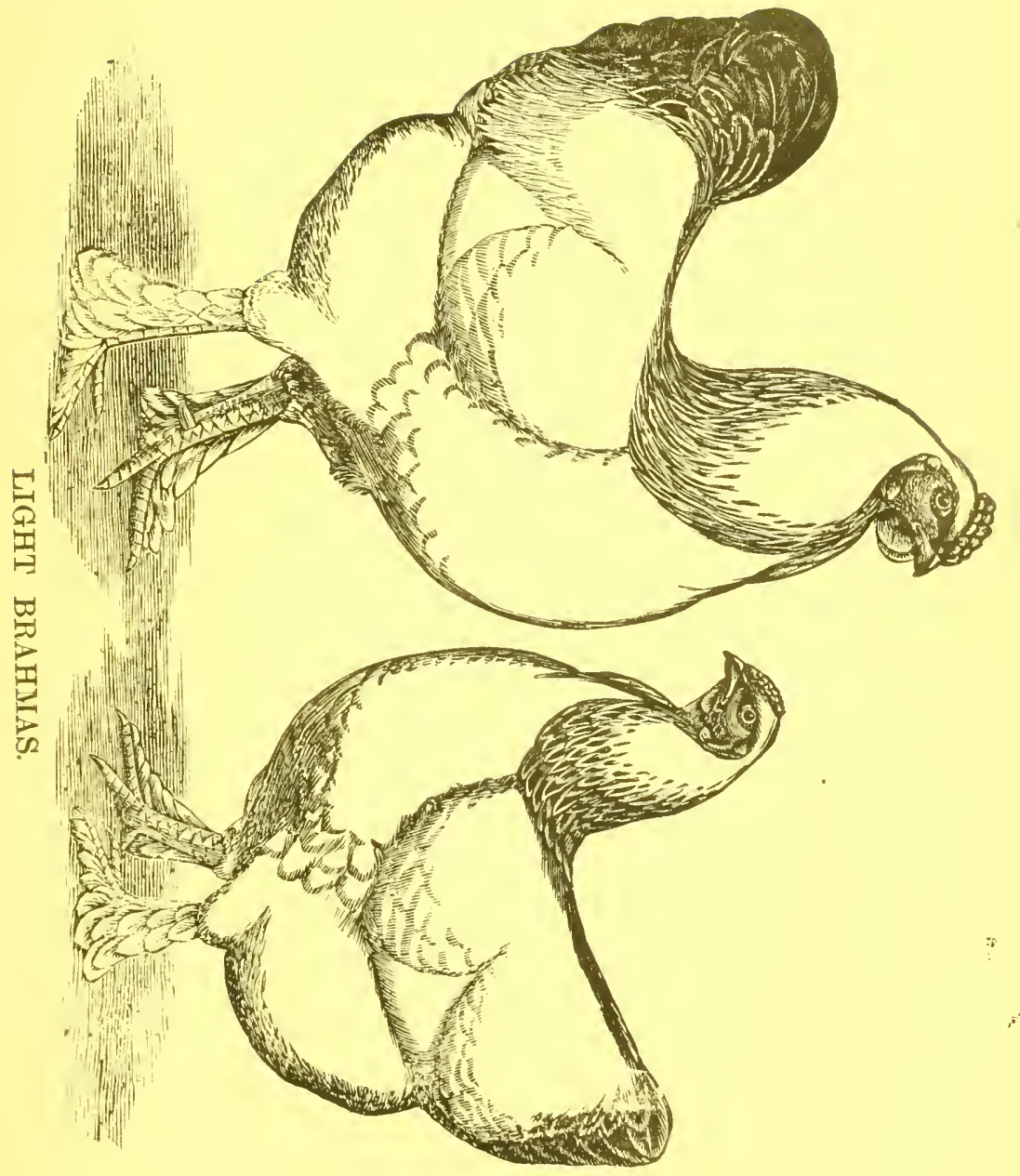


GIRLS are wanted in every country town to sell this work, to whom a liberal discount will be made.

\author{
Address, GE0. M. DAVENPORT, \\ Truth Seeker, Office, 33 CLINTON PLACE, N. Y.
}

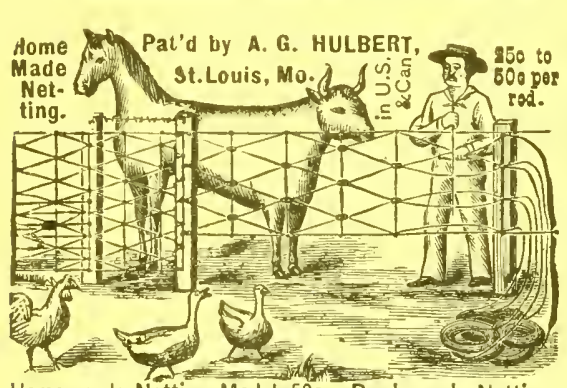

Home-made Netting Model, 50c. Ready-made Netting, Barbod and plain Wire, Iren Gates, Posts, Tools. City, Cemetery and Farm Fences, 2 c. to $\$ 1.00$ per foot. The bost Picket and WIre Fence Machine only $\$ 10$. Farmers and Aremts make Momey. Catalog free.

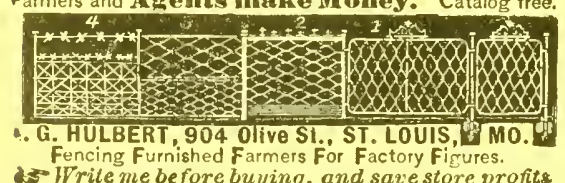

\section{CHy}

Pay, but they must be managed right to be profitable. if you keep only a dozen, or a thousand hens, to know how to care for them in Heaith, cure Diseases, Rear Chicks Build Coops, Breed Fine Birds, elc.. you want the

\section{Practical Ponltrywanl and Farmer,}

A large lllusirated Monthiy Magazine, devoted to the interests of Poultry, P'igeons, Pets and tlie Farm.

TOM. W. INDER, Managing Editor.

It is the LARGE-T FIFTY-CENT PAPFR IN THE U okzd. Sample Copy 5 cents. "Tht" Dog and How to Tiain Him " ine largest and bost book (i) the Doir ever publishid. Flumy illustrated iver 100 pages More regarding the Origin. Rearlng, Keeping. Trainlng and Management of Dors than can be had in any other book. Price 25 cents, (II the paper one year and the book for 65 cents. We want good agents to work lor us. Blg Pay.

\section{Live Stock Job Printing.}

we make a speciaity of all kinds of live stoek and poultry printing. Over 1,000 euts to selert from. Send for estimates.

The Practical Poultryman and Farmer,

uarsaw, Indiana.

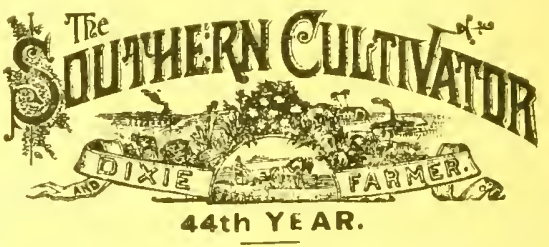

The Creat Farm, Industrial and Stock Periodical of the South.

It embraces in its constitueney the intellifent, progressive and substantially suceess ul armers of the South, and as an advertising medinm or the Merchant, Manu returer. Stork Kaiser and Proiessional Man, is ABSOLUTFLY L Nfiqualled. Sirace udiciously employed in its columns is always remunerative.

Advertisements, per line, - - - 30 .

Subseription, per annum, - - $\$ 1.50$.

Address, CULTIVATOR PUB. CO., P. 0. Drawer 8 . ATLANTA, GA.

The Franklin Publishing House Is the Leading Book and Job Printing, Blank book and clectrotyping Honse ir: the sonth. CONSULT US BEFORE PLACING ORDERS.

JAS. P. HARRISON \& CO. Gro. W. HARRISON, $32 \& 34$ W. Alabama $8 t$. , Ser'y \&'Treas'r. $\}$ ATLANTA, GA.

\section{$\$ 1,500000$}

Lost Amulalliy by Cholera and Rourp.

I have a Specific for Chicken Cholera and Roup. Any reliable Ponltry Association that will make a practical test of its merits, and give me the benefit of the test hy a testimonial, I will furnish, Free, Sufficient SPECific for same.

\section{W. W. GARIG,} Breeder and Dealer in

Thoroughbred Poultry, Dogs, Scuthern Song Birds, etc.

BOX 170, BATON ROUGE. 


\section{CIIICKENS ARTIFICIALLY

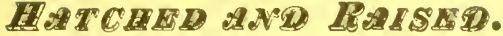

Are much stronger and healthler and attaln a larger growth at an earller age than when hatchad by the nat ural method, provlded they are hatched and ralsed by the

PERFCT HATCHER AND BROODER, which is conceded to be the only rellable and successful apparatus in the world for thls purpose. The past, year we have won the Gold, Silver and Bronze medals over all competitors at all the leading exhlbitlons, such as the clnclnnatl Expositon, the Amertcan Institute, the Madison square (N. Y.) Poultry Show, the greatest ever held ln America this year of 1884 . The clncinnatl Exposition offers us the cholce of location in their buildlngs, and go to an expense of $\$ 1,310$ to provide exira facllities for oul exhibitlon. This is an extraordinary offer, somethlng never before offered to any exbibltor. Chickens can be hatched and raised for brollers up to three months of age for 6c. per lb. or 12c. each; therefore 1t it easy to see that

\section{MONEY IS RAPIDLY MADE}

with small capital invested. A first-class market exists in every important section of the country, and can never be orerstocked. For furtier information apply to

\section{PERFECT HATCHER CO., ELAIIR.I, . r. I'.}

A FORTUNE Raising Poultry.

\author{
SUBSCRIBE FOR
}

\section{The OHIO POULTRY JOURNAL}

\author{
And Learn How.
}

A large and beaulifully lliustrated Monthly.devoted to Poultry and Pet Stock. It is full of practical suggestions, and lts correspondents are among the leading breeders of the country. It has one page devoted to the management of Bees. Prlce, $\$ 1$ per year. Sample copy wlll be sent for only SIX cents In stamps.

\section{ROBERT A. BRADEN,}

PUBLISHER ANO PROPRIETOR,

DAYTON, - OHIO.

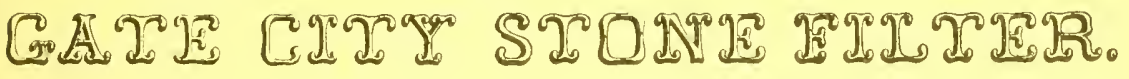

Gold Medal and Highest Awards at World's Exposition.

The filtering medium is a natural, porous stone, so close in its texture that no animalcule or other small impurities can enter its pores. It removes all kinds of spawn of worms, or insects and impure floating matter and renders the water pure, healthy and drinkable. Endorsed hy Boards of Health, Sanitary Associations, Physicians and Sorientists as the hest, simplest and most perfect filter and purifier, and is as easily kejt relean as a water bucket. Write tor price list.

Gate City Stone Filter Co.

New York City,

April 25, 188\%.

Gentumkn:- The great danger from impure water arises from the presence of living organisms of a very low order, aud these are : lsolntely mable to pass throngh the stone. Careful microscopical examination of the stone after it has been in use and then broken, shows that all solid matters are excluded, nowe of these penetrating beyond the surface. I have therefore no hesitation in expressing my belief in both the durability and efficiency of your filter.

Very truly yours,

Prof. JNO. PHIN, Eıl. Am. Jommal of Microseopy.

\section{Gate City Stone Filter Co.,}

\section{Broadway,}




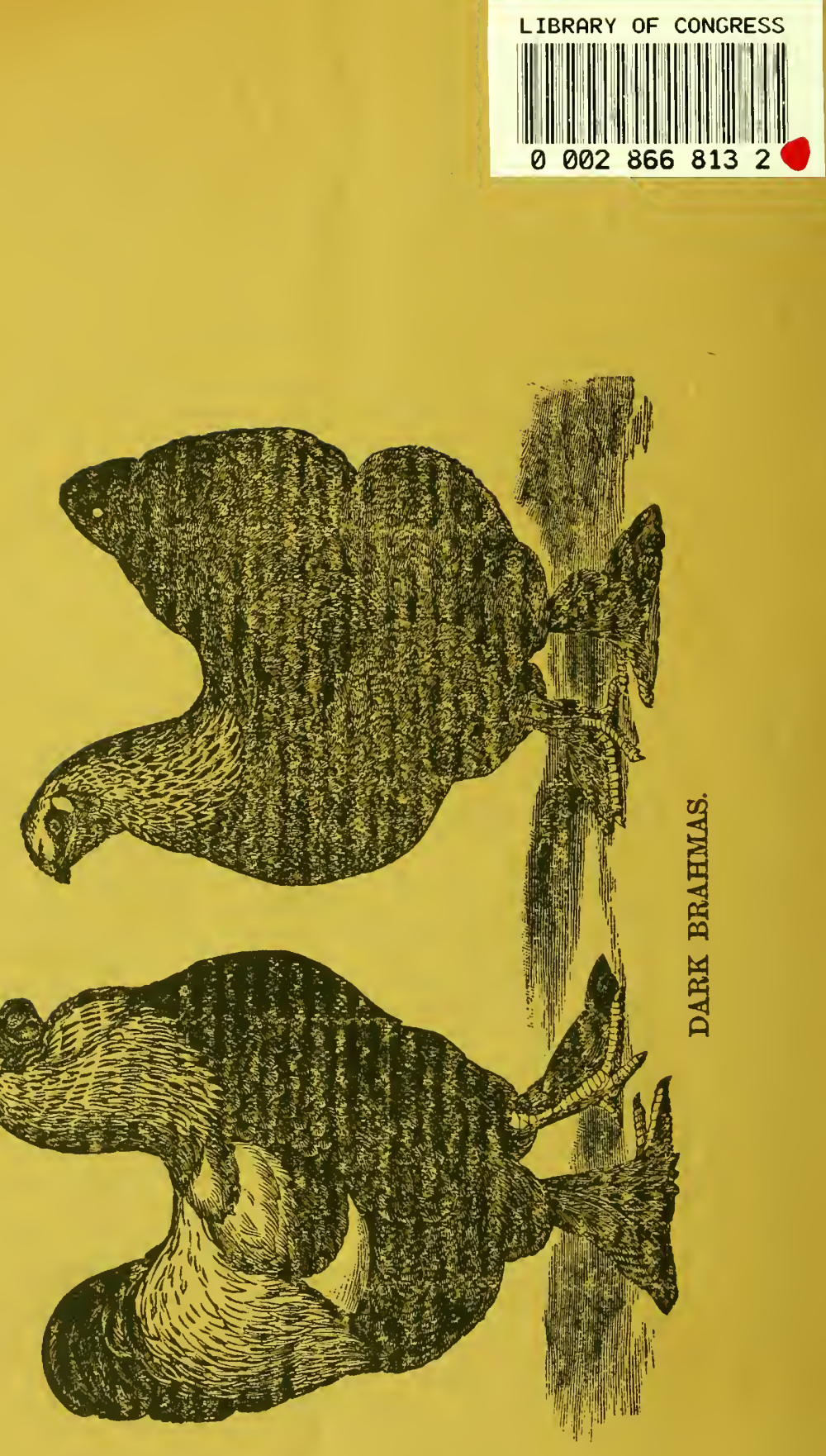